\title{
TRADITIONAL LAND TENURE ISSUES FOR LIS IN FIJI
}

\author{
Mele E. T. Rakai, I. C. Ezigbalike and I. P. Williamson \\ Department of Surveying and Land Information, The University of Melbourne, \\ Australia
}

\begin{abstract}
With the help of the New Zealand Government, a national Land Information System (LIS) is currently being implemented in Fiji, under the auspices of the Department of Lands. Like many other Pacific Island countries, Fiji has a complex land tenure system. This is the first of two papers that aims at examining the implications of LIS for traditional land tenures. Since LIS is a product of the industrialised world, attributes of the conventional 'western' land tenures can be incorporated without too much difficulty into an LIS. However, attributes of traditional land tenures are yet to be identified and incorporated into an LIS. Unless traditional land tenure issues are considered and taken into account when implementing an LIS, the LIS will not be fully accepted and utilised by the traditional peoples, and will therefore not be truly successful. The emphasis in these papers therefore will be on the features of traditional land tenures. This paper reviews Fiji's dual land tenure systems, with particular emphasis on it's traditional land tenure system, and raises some issues and problems of it for an LIS.
\end{abstract}

\section{INTRODUCTION}

Fiji's land tenure system has evolved into a dual system, like that of many former colonial Pacific Island countries. While the traditional communally-oriented system persists, a western individually-inclined system has been introduced in parts of the country, especially in the urban and commercial farming areas.

Along with other factors, this duality in land tenures has contributed to the economic disparity that exists today between the taukeit, on the one hand, and the various settler groups, particularly the Indians, on the other. The individual tenure under which the settlers held their lands facilitated access to development funds and operated on the more fertile lands. On the other hand, the communal tenure under which the taukei held their lands hindered their access to development funds since banks gave out loans to individual owners only, and not to communal owners as a whole. This situation was further exacerbated by the fact that these communal tenures operated on the generally less fertile and inaccessible lands. These factors, together with their inherent propensity to share and not hoard their material acquisitions - non-materialistic values and attitudes that had been greatly encouraged and propagated by the adopted Christian religion and the Colonial Government - resulted in their being little incentive for the taukei to invest on the land. Despite many attempts by the ruling administrations in the past to narrow the economic gap between the taukei and the settlers, little visible success has been achieved. Unless this disparity is bridged, Fiji's social, economical, and political stability will always be threatened.

In addition, modern development and technology is affecting the relevance and nature of the existing tenure systems. Although much of the development and technological changes can be seen as advancement, there may be 'cultural costs' involved, as Ezigbalike and Benwell [10] rightly point out. Thus as the rate of

$\dagger$ taukei: The indigenous Fijians. 
urbanisation increases, and the standards of education, communication (radio, telephone, television), and transportation routes improve, the traditionally strong bond that the taukei had with their land is slowly being loosened. Furthermore, the taukei's growing desire for a greater share of, and contribution to, the Republic's wealth conflicts with their desire to retain their largely non-materialistic social customs and traditions. The resolution of these conflicts require access to all information relevant to the Fijians and their land.

A Land Information System (LIS) provides information about the land, its resources and the improvements made to it. It (LIS) is defined here as being: 'a system for managing land information, that uses modern technology to create an information database and disseminate land information, but is ultimately controlled by the surrounding institutional and social framework'. With its ability to quickly collate and integrate land related information from several sources and make them readily available for decision making, an LIS provides a way of determining how the taukei's conflicts may best be resolved.

To date, practically all LIS's have been designed for the rigid, well documented tenure systems of the West, and attempts are only now being made in some countries, such as New Zealand, to cater for traditional land tenure systems. Given the spread of westernisation, including more particularly that of modern technology and communications; and that two thirds of the world still operates under traditional tenure systems (de Soto, [7]), it is inevitable that LIS will eventually be introduced into such countries. However, the LIS will not be fully accepted and utilised by the traditional peoples, and will therefore never be truly successful, unless the traditional land tenure issues of such countries are considered and taken into account when implementing an LIS.

This paper is one of two papers written by the authors. The aim of this first paper is to review Fiji's land tenure systems - in particular its traditional land tenure systems - and identify issues that could be relevant for implementing a land information system for Fiji. Included in this review is the historical background to Fiji's traditional land tenure systems, in order to portray how they have been shaped and modified by varying colonial policies and are therefore not as indigenous or 'traditional' as many Fijians believe. This will be followed by a comparison of the various land tenure systems, before highlighting some of the issues and problems that the dual systems raise in Fiji today. A future paper will look at areas where an LIS could be used to document the issues, as a step towards resolving some of Fiji's land tenure-related problems.

\section{Pre-Colonial Land Tenure}

\section{General Features}

Land tenure refers to the way in which people obtain, use and distribute their rights to land [5]. Because it is concerned with people, it is also involved with the complexity of relationships that arise between the members of a society, as a result of their occupation and ties with the land [10].

With regard to the rights to land, and their associated relationships, three features of pre-colonial land tenure systems distinguish them from western systems : 
- Firstly, there were no written records of these systems at the timearrangements were legitimated and publicly endorsed at public ceremonial gatherings, where members of both sides were present.

- Secondly, the smooth functioning of these systems depended largely on maintaining amicable relationships within the society. There were no hard and fast rules laid down, as in the present day 'western' tenures. Modifications were made in accordance with the prevailing circumstances of the time. Thus rights were legitimated by the community's recognition and acceptance of them.

- Thirdly, since land was plentiful for the sparse population and was used for subsistence farming, the concept of land as a 'property' that could be bartered or exchanged for monetary purposes was unheard of.

Acquaye [1] has suggested that the following features could be considered to be common attributes of pre-contact traditional tenure:

1. Land rights were in all cases vested communally in groups.

2. Communally owned lands are usually held fiducially by the head of a group, for the whole group, e.g. by chiefs, who receive gifts/payments made for land on behalf of the group.

3. Although held communally, land is not used communally, by the group at large. In practice, land is actually used on an individual basis by a family or household. Exceptions to this norm apply to the communal rights attached to the larger, communally used areas, for example, for water rights, fishing rights, grazing rights.

4. Individual rights may be acquired either by land-owning members of a group - for example through matrilineal or patrilineal inheritance; or, as long as land was in abundance, by non-land-owning members of the group, through usage or need.

5. Individual rights may revert to a larger group:

- if land is abandoned;

- if a sub-group dies out;

- if allegiance to a group is renounced or rejected;

- if a temporary right expires.

6. Absolute rights to land are not transferable in principle, even though warfare, famine, migration, fear of sorcery or other factors might lead to such transfers.

7. Some social, mystic and religious attributes are usually attached to land, e.g. sevusevu $\dagger$ to landowners and chiefs required before going on to new lands.

R. G. Crocombe [1993, personal communication] also noted that in addition to the above principles, several others applied: the rights of males were generally superior to those of females; the rights of older siblings superior to those of the younger ones; those of residents to those of absentees; and those of users to those of non-users. In addition, personal assertiveness, negotiating ability and other personal factors influenced the outcome in any particular case. When principles conflicted, as they often did, compromise and leadership was necessary to determine which principles (or pragmatic solutions) would apply.

$\dagger$ sevusevu: Traditional ceremony for introducing a visitor and obtaining consent to carry out activities in the area. 


\section{Transfer of Land Rights}

Land-rights were acquired or transferred by a variety of ways, the main one being through inheritance from either the mother or the father. Inheritance however was conditional on various other criteria. These included place of settlement, the need for land, use of land and number of children. Land could also be acquired in other ways, such as by gift, by a reward for past services or help, by consenting to the needy requests of new arrivals, or through conquest in times of war. These latter rights are usufructuary or use-only rights and could only be guaranteed by the occupants' continual use of their piece of land, by their good relations with the community, and by their meeting their obligations to the community. Failure to meet the community requirements of the time meant that the land could be allocated to someone else. This meant that land was acquired and distributed under a flexible system, in response to the circumstances prevailing at the time.

\section{Summary}

In summary, a general description of the pre-Colonial land tenure systems is that it was subsistence-oriented, based principally on continuous occupation and use of the land, and honouring the obligations that came with the land. Land was highly valued, either for its utilitarian, emotional, mystical, social or religious uses, but did not have any exchange value, commercially.

\section{HistORICAL BACKGROUND}

\section{Diversity of Traditional Tenures}

As Figure 1 shows, Fiji was first successfully colonised by Melanesians about 3500 years ago. The next colonising group were the Polynesians, about 500 years later. The successive waves of colonisation by these two main groups of people since that time resulted in the existence of numerous varieties of cultural and land tenure systems in Fiji, by the time the Europeans arrived in the country.

Various writers $[\mathbf{1 1}, \mathbf{2 0}, \mathbf{2 2}]$ have noted that in the eastern parts of Fiji, where Polynesian influence was particularly strong, a hierarchical social structure existed which gave dominant rights of land distribution to the chiefs. Here it was acceptable for a chief to have the final say, with the acquiescence of the community involved, on who was entitled to what land, and which land could be disposed of at his discretion. Cases of lands being disposed of without the approval of the community have occurred, as when the community had been conquered by the chief, and/or individuals or sections of the community had been disobedient to the chief.

However in the rugged interior and parts of the western areas of Viti Levu (Fiji's main island), where Polynesian influence had not been significant, a less structured, non-hierarchical system existed. In this system, a chief mainly served the purpose of leadership in times of war, but had little right to allocate land to anyone.

The immense varieties of land tenures therefore made it difficult for the European arrivals to define a land tenure system that could be universally 


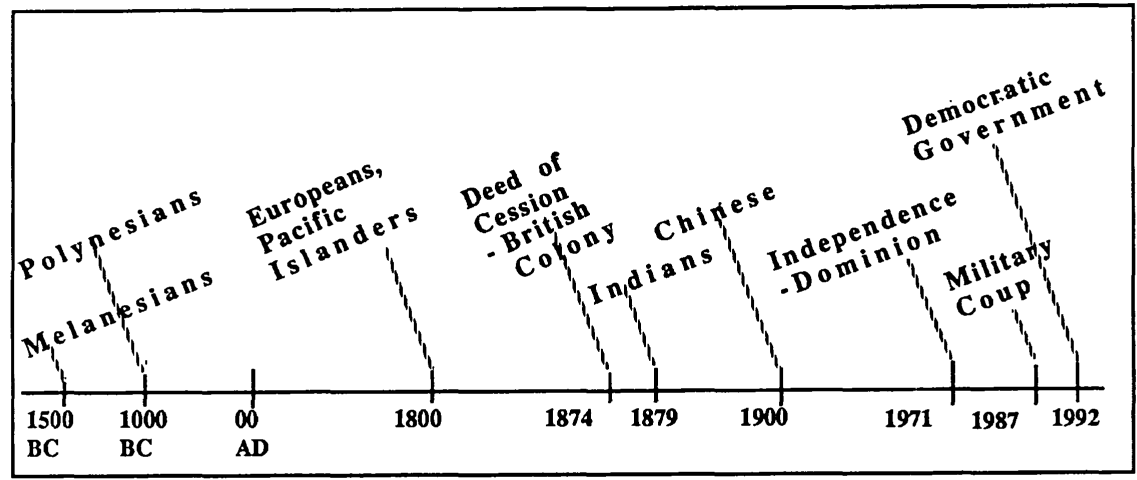

Fig. 1. History of Colonisation and Government.

attributed for the whole country. France [11] notes 'the unqualified failure' of attempts made by the British Administration, during its first 30 years of rule, to satisfactorily define traditional Fijian social structure and land tenure.

\section{Foreign Influence}

With their feudalistic backgrounds, it was easy for the first arrivals and, later, the British Colonial Administration, to identify with the social hierarchical societies of eastern Fiji. The missionaries, with their biblical patriarchal concepts, also identified easily with the eastern hierarchical system. And, since it was easier for the newcomers to deal with only one individual rather than a whole community, they encouraged and fostered the establishment of the chiefly hierarchical system throughout Fiji. This facilitated their eventual acquisition of land needed for their missions and settlement. Paradoxically, this arrangement also suited the chiefs who exploited the newcomers for their own personal ambitions.

\section{Existing Traditional Land Tenure: A Combined Colonial and Fijian Tradition}

France [11] has pointed out that much of what has now come to be regarded as being customary or 'traditional' land tenure is actually a customary tenure system that has been greatly influenced, moulded and modified, almost beyond recognition by two major events.

Long before colonisation, the first major influence was Polynesian migration. These mainly Tongan migrants brought with them their distinct hierarchical system of ascribed or inherited chiefly leadership. The impact of this on the earlier Melanesian style of achieved leadership has been described earlier, where a pattern of heritable, Polynesian styled system emerged in the east, and the pattern of self achieved, Melanesian style remained dominant in the west.

The second major event was the colonisation of Fiji by the British. By introducing firearms, establishing peace, promoting Christianity, introducing commerce and, most importantly, a system of centralised administration, they significantly modified the 'customary' land tenure system of the time.

Fiji officially became a British colony in 1874 . With its centralised system of Government, the British rulers needed an administration system that would not 
only be based on simple, easily understood principles, but would also be inexpensively initiated and maintained.

One of two significant actions taken by the British Administration was to introduce a system of indirect rule, or 'Native Administration'. This innovation served the dual purpose of not only establishing a centralised system of Administration that would allow them to control the taukei, but was also in line with the existing British protectionist policy of preserving and protecting the indigenous cultures and their land. The 'Native Administration' or 'Fijian Provincial Administration' as it is now called, was a form of local government that had jurisdiction over all Fijians at the provincial level. It comprised the Great Council of Chiefs as the advisory body at the top of the hierarchy, the Fijian Affairs Board (FAB) $\dagger$ as its administrative arm, and local chiefs at the district and village level to oversee the daily affairs of the taukei.

However as Ravuvu [18] noted, apart from carrying out its customary responsibilities there was little if any, 'local government', since the districts and provincial offices were administered, financed and controlled from their headquarters in Suva.

A result of this direct and indirect rule, or combined Native Administration for Fijians and British Administration for non-Fijians has been that over the years, various administrations have been set up, for different functions which sometimes overlap (See Table 1.)

The other significant action taken by the British Administration was to classify Fijian social structure into a generalised hierarchy that they could readily understand and work with. Native Land Commissions were set up for this purpose, but as mentioned earlier, the immense varieties of the traditional social structures and tenures defied their attempts for the first thirty years. Finally in 1913, pressured by the political and economical stringencies of the day, a broad classification of Fijian social structure was drawn up. This classification (shown in Fig. 2) was supposedly based on evidence obtained from fieldwork. However, the reliability and the comprehensiveness of this six-month field work has been questioned:

And so the social unit of the Fijian people which successive Native Land Commissioner's had discovered to be most remote from the exercise of land rights was gradually transformed, through a number of causes unconnected with Fijian custom, into the legally registered owner. [11]

Fiji's traditional land tenure has since been based on this classification, which is based largely on that part of Eastern Fiji that in former times had been a Confederacy of Bau, and was characterised by its distinct hierarchical system of control and authority. Under this classification the mataqali was selected as being the most common land owning unit. Yet the fact that the classification was not truly representative of the whole country was indicated by the fact that even the chiefs themselves, the 'indirect rulers' of Fiji, in their debates on the subject, could not unanimously agree on definitions for the $i$ tokatoka or mataqali [11]. Even

$\dagger$ The FAB is responsible for initiating and implementing policies relating to the affairs of the taukei. Under the Fijian Affairs Ordinance it is empowered to enact rules and regulations that govern native customs, including land customs.

$\ddagger$ mataqali: The exogamous social unit of the Fijians. It is patrilineal and is the recognised landowning group. It is usually a primary division of the village. 
M. E. T. RAKAI, I. C. EZIGBALIKE AND I. P. WILLIAMSON

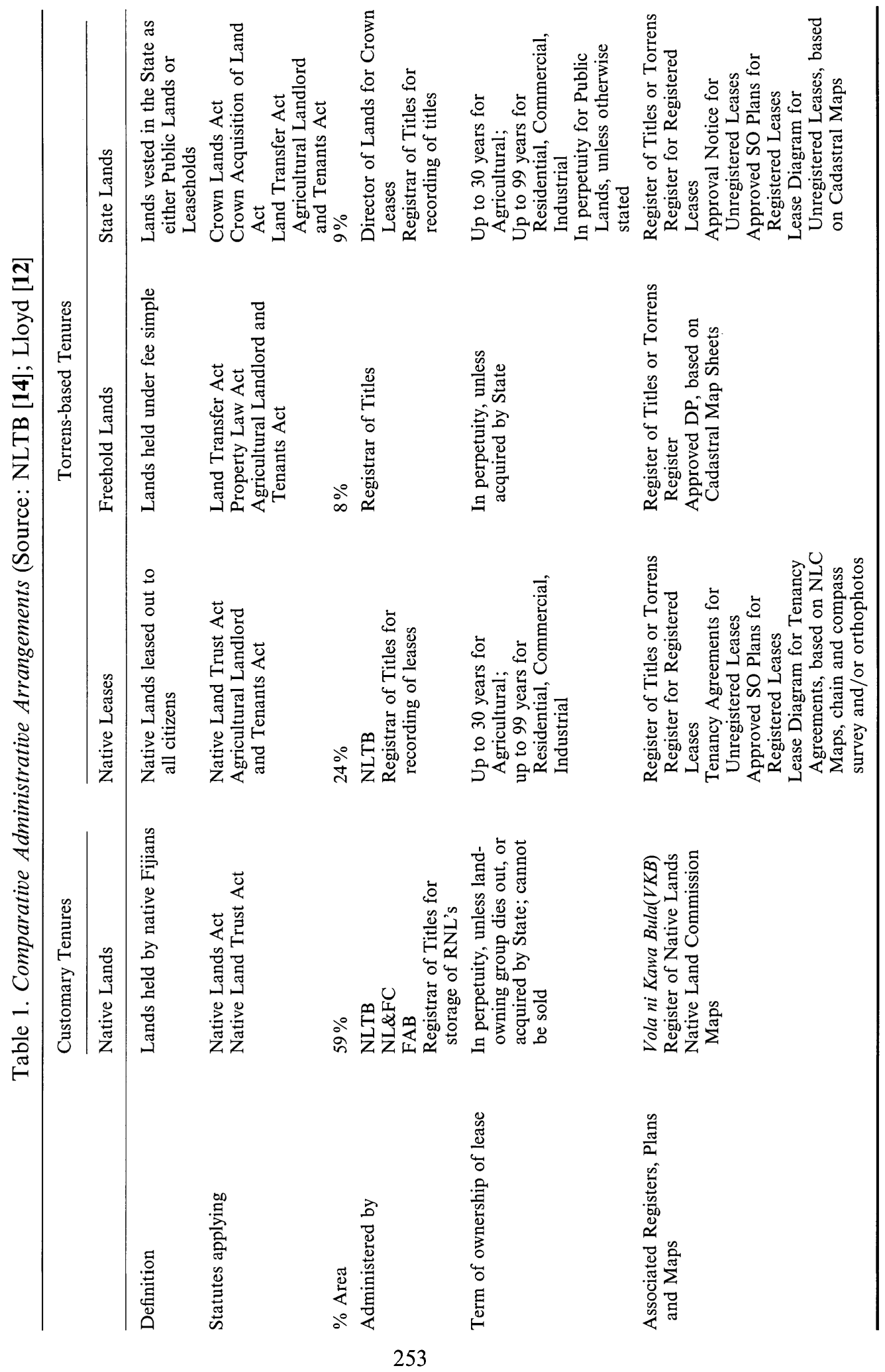




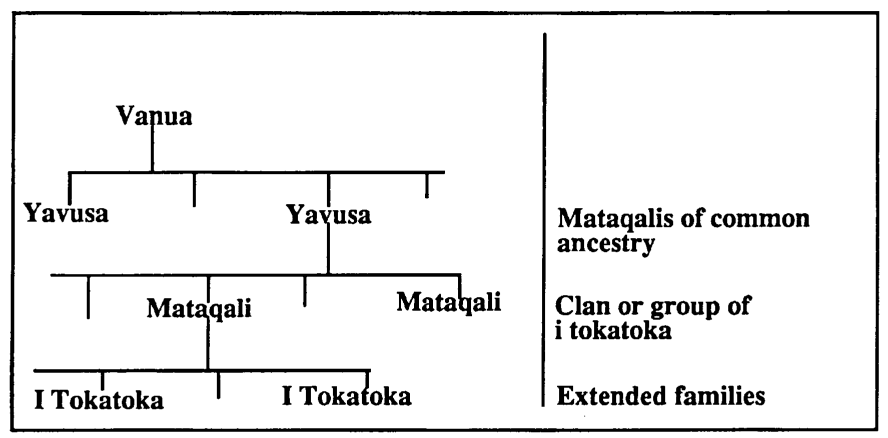

Fig. 2. Classification of Fijian social structure.

today this classification sits uneasily upon the taukei, where their response has been to exploit the deficiencies in the resulting tenure system [15].

\section{Fiji's Land Tenure Systems}

Fiji has three main types of land holdings: Freehold Lands, State Lands and Native Lands. As Figure 3 shows, these are held under two different types of land tenure systems: a 'western' land tenure system, and a 'traditional' land tenure system. Freehold Lands, State Lands and the portion of Native Lands that are leased out as 'Native Leases' operate under the 'western' land tenure system; while the communally held Native Lands operate under the 'traditional' land tenure system.

\section{The Western Land Tenure System}

This system is based on European-styled, capitalist-oriented concepts, and is intended primarily to facilitate land conveyancing and land and economic development [24]. With its emphasis on individual land ownership, it applies, as previously mentioned, to Freehold lands, State lands, and Native Leases. It is based on the Torrens Title Registration System and, because it is oriented towards individualistic commercial enterprises, an accurate Cadastral Surveying and Mapping System.

Freehold lands are lands that are held individually or corporately in fee simple, and are guaranteed by the Government.

State Lands are all Public Lands in Fiji, and include all lands below high water mark, including mangrove swamps and all foreshores; those held by the State for Public Purposes, such as roads, reservoirs, dams, drains; and those held by the State for leasing, for either residential, commercial, industrial or agricultural leases. It presently also includes those lands that had not been claimed by Fijians when Fiji became a British Colony in 1874 (State Schedule 'B' Land); and those Native lands for which the mataqali or land-owning group have since become extinct (State Schedule 'A' Land). However these lands are in the process of gradually reverting back to the taukei.

The Freehold and State lands account for only $16 \%$ of Fiji's total land area, but as Crocombe [3] notes, this figure is 'misleading and irrelevant', because in terms 


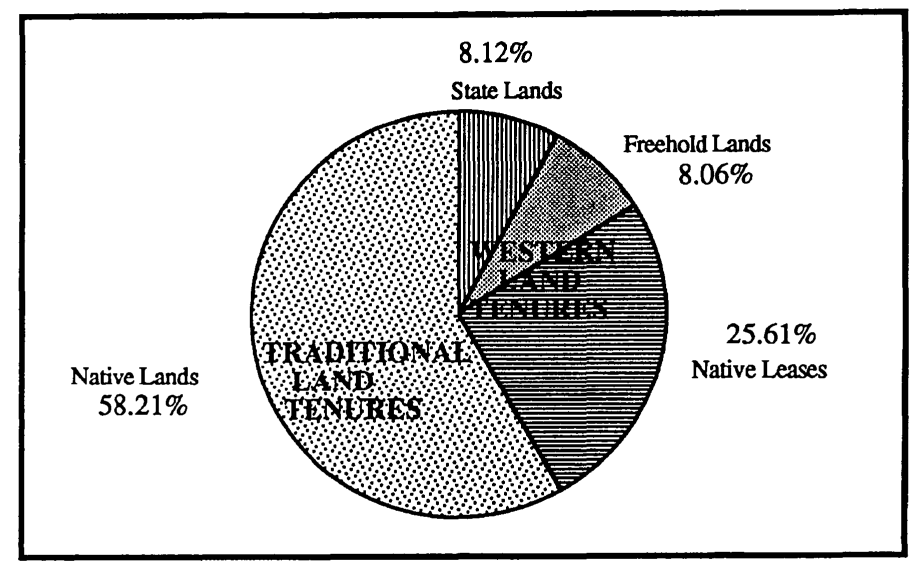

Fig. 3. Comparison of land tenure by areas.

of value, they include the best urban, commercial, industrial and agricultural lands. They account therefore for most of Fiji's land assets, and are owned generally by non-indigenous Fijians, mostly Indians. As mentioned in the introduction, this has been a contributing factor to the economic disparity that exists in Fiji between the taukei and the non-indigenous Fijians.

Native Leases are those Native lands that have been leased out: largely to allow the lands that were not being used by their taukei land owners, to be used by the other people of Fiji, including the non land-owning taukei. These lands make up the small proportion of Native lands that are more accessible and arable $(31 \%$ of all Native Lands, or $25 \%$ of Fiji's total land area), and are found obviously, in the more valuable agricultural areas such as the cane growing lands, and near the main urban centres. All legal dealings relating to Native Land, such as the issuing of leases, agricultural licenses, timber concessions, land subdivisions, etc. are handled by the Native Land Trust Board (NLTB). The NLTB is a statutory body that was set up in 1940 under the Native Land Trust Act, to administer all Native lands for the benefit of Fijians and, paradoxically, for the nation as a whole.

The advantage of this 'western' tenure system is that dealings for lands held under this system are straightforward and can be efficiently completed, and tenure over these lands is generally secure and guaranteed by the Government.

Administration of lands held under this system of tenure lies with the Department of Lands and the Registrar of Titles for Freehold and State Lands; and with the Native Land Trust Board and Registrar of Titles for the Native Leases. Table 1 lists some of the features associated with the administration of the lands held under these land tenures.

\section{The Traditional Land Tenure System}

This system is based on supposedly Fijian customs and traditions, and applied to all unalienated Native Lands, until they become alienated Native Leases, to which the 'western' system applies. The term 'Native Lands' refers to lands that belong to the taukei, the indigenous Fijians, and are held in accordance with their customs and traditions. With the exception of the portion of lands that are leased 
out, Native Lands include those lands that are farmed/used by the taukei for their subsistence and, increasingly, commercial needs, as well as Native Reserves - lands that in principle, have been set aside to be used exclusively by the Fijians only. However, as Eaton [9] pointed out, some of these lands have been leased to Indians under the customary or vakavanua arrangements.

Though Native Lands are supposed to make up almost $84 \%$ of Fiji's total land area, in reality they comprise about $53 \%$, since $31 \%$ of this area is actually accessible cultivable land, which is usually leased out, mainly to non-Fijians. The $53 \%$ of lands held by taukei under their traditional land tenure system are therefore in more difficult terrain, not easily accessible, and of lower quality, to use.

Lands under this traditional land tenure system work on the principle of communal ownership of a land parcel that has already been topographically surveyed, charted on Native Land Commission (NLC) Maps, and registered in the Register of Native Lands (RNL). Under this system land and communal land owners are registered, with no individual titles being issued. Ownership of land is vested in the mataqali or tribal group as registered in the RNL. Individual membership of the land owning mataqali is recorded in the Vola ni Kawa Bula $(V K B) \dagger$.

The Native Lands Commission (NLC), established under the 1905 Native Land Ordinance, is responsible for maintaining the $V K B$, and solving land and fishing rights disputes. It was originally established by the British Administration to investigate, by a series of inquiry sittings, the nature of Fiji's land tenure systems. This necessitated the execution of NLC topographical surveys that were carried out by a variety of methods, ranging from those using prismatic compass, tape and plane-tables [12], to those using conventional surveys, and even aerial photography and photogrammetry [8].

The compilation of these topographical surveys gave rise to the existing NLC Maps, which are still in use today. The investigations of the NLC also gave rise to the Register of Native Lands (RNL), which records the names of the mataqali or land-owning units, the Native Land Commission (NLC) Map reference, and the size and NLC lot number of the land parcel. It (RNL) is maintained by the Register of Titles.

Native lands cannot be sold; and any dealings or works to be done on or with respect to the land requires the approval of the majority of the members of the mataqali that are over 21 years of age. Legally the final approval/decision rests with the NLTB. Although Native Lands cannot be sold, they can be officially leased out, with the consent of the mataqali landowners, through the NLTB. Once leased out they naturally come under the 'western' system of land tenure for the duration of the lease, as previously mentioned.

The advantages of the traditional tenure system for the taukei is that it has firstly, prevented outright land sales and land speculation, and thus has ensured that they have not become a landless people in their own land. Secondly, it has helped the taukei to maintain their land-based customs and traditions, which are based fundamentally on the maintenance of family and kinship ties, and ultimately on the basic principles of sharing and caring - a principle that has prevented the 
Fijians as a whole from being swept away by the materialism of the modern age. Ironically however, it is this very principle that has been one of the major stumbling blocks in the taukei's quest for economic progress.

Administration of the lands held under this system lies with the:

- NLTB - for all matters relating to their land, whether it is for leasing, for acquisition for public purposes, for improvements to be made to the land through major capital projects, or for compensation for any loss of land or damages sustained;

- NL\&FC - for all land and fishing rights disputes;

- $\mathrm{FAB}$ - in so far as their rules and regulations affect the native land customs.

\section{Some Issues and Problems of Fiji's Traditional Land Tenure System}

\section{Existing System out of Touch with Reality}

The traditional land tenure system was intended to preserve for all time, the lands and customs of the taukei. However, as stressed earlier, the existing customary tenure system is based on the British Administration crystallising a system that was in operation at a particular place and time (i.e. in the late nineteenth century, in the Bau-dominated region). Given their non-Fijian background, and the economic and political constraints of the time, it was only natural that they would modify or exclude some seemingly less important but quite significant details in the system that they imposed on Fiji [18]. For instance, imposing the mataqali social structure into the whole country effectively forced mataqali that were numerically smaller to be incorporated into the larger mataqali groups. Ravuvu [18] notes however that there are times when the smaller, officially non-existent mataqali still retain their own identity, despite having been officially subsumed by the larger group.

Thus, while adopting the system as it stood then may have been the best solution at that time, it has now become quite incongruous with existing realities. For instance some of today's young urban Fijians are not aware of their tribal groupings. This is understandable since knowledge of their respective tokatoka, mataqali, or yavusa groupings is really needed only at certain times, such as during election times, for land disputes, or when consents are required for development works (which they may not have an interest in, being long-settled out of their villages).

Refer to Nayacakalou [15] and Ravuvu $[18,19]$ for examples of how the existing system has come to be out of touch with reality.

\section{Disincentives of Customary Group Ownership of Land for Individual Enterprise}

Although the fact that Native Lands cannot be sold has had the advantage of ensuring that the taukei would not be dispossessed of their lands, it has also disadvantaged them by discouraging the more enterprising members of the village (or those foreign to the village but who have long settled into it) from developing their lands further. For instance, there are many cases where an individual's initiatives or hopes for development and/or expansion are stunted by the failure to obtain the necessary mataqali approval, as a result of rivalry, jealousy, or grudges held against the individual by other members of the mataqali. The lack of 
mataqali approval means that finance for the scheme cannot be obtained, and the scheme inevitably falls through. Land which could have been more productively and/or efficiently used is therefore left undeveloped and under-used.

Another well known fact of customary group ownership is that it leaves the aspiring individual farmer very vulnerable to unintentional 'exploitation' by his fellow mataqali members-i.e. there is the not unnatural tendency for the remaining villagers to ask the 'successful' individual farmer for donations from either his crop or his livestock, when a death, birth, or celebration requires it. The continuing incidence of this has led invariably to the failure of the individual farmer's enterprises.

\section{The ALTA Issue}

Given the track record of the failure of the taukei to competitively farm commercially, the inherent fact that the Native Lands cannot be sold and only leased, has tended to be viewed as a striking disadvantage for both the national economy and the Indian farmers in particular; a view that has been the subject of much discussion and writings $[\mathbf{1 2}, \mathbf{1 3}, \mathbf{2 1}]$. In order to rectify this situation, which has long been a particular problem of the Native Lands in the cane farming areas, the Agricultural Landlord and Tenant's Act (ALTA) was passed in 1977, enabling agricultural lessees to obtain a maximum of 30 year leases. Because the sugar that comes from these cane farming areas is Fiji's main export earner, the expiry of these agricultural leases under ALTA from 1977 constitute the most crucial issue facing Fiji at the moment.

ALTA was devised to provide lessees with a secure tenure for the thirty year term of their lease. It applies to all lands under agricultural use with the following exceptions:

- lands under 1 hectare,

- lands held cooperatively by a group or co-operative society,

- unsurveyed areas, such as land in Lau, and the interior of Namosi,

- Native Reserves.

The problem with ALTA is that it only applies to new leases and does not allow for any extensions once these leases have expired. This means that it is not entirely clear what will happen to all leases that are due to expire from 1997. One option could be to extend the leases under the Native Land Trust Act (NLTA). However this may not provide lessees with the same security of tenure that ALTA provides, as under the NLTA lease extensions can be refused if the taukei are able to convince the NLTB that the leased land is needed for their own use and long term welfare. Consequently the question facing the country now is whether to extend the ALTA leases or not.

Not extending the leases will give the taukei farmers the opportunity of reoccupying and controlling their own lands and proving that they are now capable of competing commercially with the other races in Fiji. However, past trends and studies [17] have shown that taukei farmers are not as productive as the more experienced and better equipped Indian farmers, and this, in the context of Fiji's national economy, is of great concern to the Government.

Extending the leases will therefore ensure that Fiji's economy will not be adversely affected. However, this measure will antagonise the taukei landowners 
that have become increasingly interested in commercial farming, and have thus been crying out for the return of their lands at the expiry of the present leases. Brookfield [2] notes that about $25 \%$ of all taukei farmers have been estimated to be now living on and farming lands that have been leased from the NLTB.

Not extending the leases will also raise the questions of compensation for improvements, and mass relocation of farmers - who will pay the compensation accruing to the outgoing lessees?; and where will the outgoing lessees go? The economic and social consequences of both questions could cripple the country. As the clock ticks, the answer to this long elusive problem of Fiji's land tenure is still being sought.

However, the fact that both ALTA and the NLTB effectively forced the taukei landowners to lease their lands to others, principally Indians, at rates well below their market value, indicates that in practice, the Indian lessees have tended to be given priority over the taukei landowner, for the sake of maintaining the national economy. With this precedence in mind, and the fact that the Fijians have always been a very tolerant and accommodating people, it is very likely that the economic development of the Fijian cane farmers will once again be sacrificed for the sake of the national economy.

\section{Minimal Benefits for Individual Landowners of Native Leases}

Under the NLTA all legal dealings and transactions are handled by the NLTB, with the resultant proceeds being divided between the NLTB (25\% maximum); the Chief of the Vanua $(3.75 \%$ maximum); the Chief of the Yavusa $(7.5 \%$ maximum); the Head of the Mataqali (11.25\% maximum); and the individual mataqali members collectively ( $52.5 \%$ maximum).

The establishment of the NLTB effectively stripped the taukei of their control over their own lands. This has been a source of discontent and great dissatisfaction amongst the taukei for two reasons:

- the best of their lands were effectively alienated by lease to others, mainly Indian farmers - for a maximum of 30 years under ALTA - and despite their best plans for cultivating it, there was no way that they could touch it;

- the split formula as described above, for distributing the rental proceeds has been a continuing source of discontent.

Speaking in parliament in July 1992, Tuisawau [23] pointed out that 'native land owners were receiving only $3.75 \%$ in rent after development costs' taken out by the NLTB. This ridiculous situation suggests that the individual land-owning member of a mataqali could be better off utilising his land himself, rather than sacrificing it for a lease from which he obtains a mere pittance. This situation will need to be addressed if the Government is to avoid a future crisis, particularly in view of the fact that, as previously mentioned, many of Fiji's sugar-cane leases are due to expire, under ALTA, from 1997.

\section{Leasing by Vakavanua Arrangements}

In order to bypass the NLTB leasing arrangements, with its associated loss of control over the land and minimal benefits, some taukei have been utilising the customary or 'vakavanua' system of allowing a non-mataqali member, without the 
officially required sanction of the NLTB, to use their land for an agreed period of time. Despite not having any legal status, this has been a widely practised tradition, and is being used increasingly by the taukei in order to obtain 'immediate, cashin-hand profits' [9].

This vakavanua arrangement is one where an individual requests permission from the taukei to use the land. The request is normally made by a ceremonial presentation of sevusevu, where yaqona $\dagger$, supplemented with tabua $\ddagger$ or cash is offered to the taukei. The onus is then on the individual to pay or 'share', voluntarily or as agreed upon with the taukei land owner, a part of the proceeds of his use of the land.

This practice naturally lends itself to much abuse. For instance some taukei landowners have been known to demand payments as much as ten times above those of the NLTB rates [9]. However, this practice provides advantages for both the taukei landowners and their tenants in that it allows the taukei landowners to receive more money from their tenants and to have more direct control over both their tenants and their land; and it provides the tenants with access to land that could otherwise have not been available to them - e.g. use of Native Reserve Land, which legally is only meant to be used by Fijians only, but is actually used unofficially by non-Fijians under this vakavanua practice.

The disadvantages of this practice are the insecurity inherent in the fact that it is not a legally recognised practice, the lack of control over any abuse of the practice, and the tendency for the land to be over-utilised, with little thought of conservation, during the term of the agreement.

In his study of tobacco growers in Sigatoka Eaton [9] found that lands held under the vakavanua land tenure system were more productive than those held under the legalised leases administered by the NLTB. Although this effect may be an isolated one, or is characteristic only of the tobacco growing industry, it does show that there is room for successful enterprises for lands held and managed under customary enterprises. Eaton [9] in fact concludes his essay with a call for these illegal vakavanua land tenure arrangements to be officially recognised and sanctioned.

\section{CONCLUSION}

This paper has attempted to review Fiji's dual land tenure systems. Although most of the taukei were not dispossessed of their lands, they have not been able to capitalise on this and fully utilise their lands, for various reasons. Added to that was the fact that what lands they had been left with has not always been sufficient for their needs, being largely marginal, inaccessible lands. The result is a glaring economic disparity between the taukei landowners and the large, relatively landless Indian communities.

The description of Fiji's dual land tenure systems, and the discussion of some of the issues that followed, reveal the complexity of Fiji's land tenures and its consequent tenure-related problems: a complexity which in the past has been naturally difficult to document and therefore understand. The following conclusions can be drawn, with respect to Fiji's land tenure systems:

$\dagger$ yaqona: The ceremonial drink made from the root of the yaqona plant. Also known as kava or scientifically, piper methysticum.

$\ddagger$ tabua: A whale’s tooth, used for ceremonial exchange or for appeasement for grievous deeds. 
(1) that the existing customary tenure system is not the same system that was practised by the Fijians before contact with the Europeans;

(2) that the existing customary land tenure system is in effect a colonially inspired customary land tenure system;

(3) that the existing western land tenure is a fossilised version of the system imposed into the country by the early foreign settlers, in the first half of the nineteenth century

(4) that despite many studies on the subject, the Fiji Government has been reluctant to introduce any changes in its land tenure systems, due partly to the dearth of reliable information that it could base its decisions on.

The ability therefore of an LIS/GIS to integrate, reflect and analyse a variety of themes or layers of information, provides a way of efficiently documenting and displaying Fiji's land tenure related problems.

An area in which an LIS will undoubtedly be useful will be in improving the complex and confusing administration of Fiji's present land tenure systems. This would have many flow-on effects, of which an important one would be to facilitate the development of, and movement towards, much needed reform in the existing colonialist-inspired tenure systems.

However, it is important to remember that an LIS is only a tool to be used by administrators, planners and land-users, to help them in planning their work/resources. It (LIS) exists merely to provide, for instance, information about the land, the resources upon it and the improvements made to it, which then allows future patterns or events to be predicted. It thus offers the opportunity of compiling inventories of all interests in land (e.g. social and spiritual interests), and at the same time, to study and monitor existing land tenure practices (e.g. longstanding occupation and use). As such, it will not in itself directly improve or reform the existing land tenures, but the information it provides will, for the first time, provide managers, planners and administrators with enough reliable information to allow them to understand the complexities, weaknesses and strengths of Fiji's existing land tenure systems, and so place them in a better position of finding solutions to Fiji's land tenure-related problems.

\section{References}

1. Acquaye, E., 1984. Principles and Issues. Land Tenure and Rural Productivity in the Pacific Islands. FAO, Rome; Institute of Pacific Studies, University of the South Pacific, Suva; and South Pacific Regional Environment Programme, Noumea.

2. Brookfield, H. C., 1988. Fijian Farmers Each On His Own Land: The Triumph Of Experience Over Hope. The Journal of Pacific History, 23 (1): 15-35.

3. Crocombe, R. G., 1984. Registration, Security and Productivity in the Pacific Islands: Experiences and Potential. Land Tenure and Rural Productivity in the Pacific Islands. FAO, Rome; Institute of Pacific Studies, University of the South Pacific, Suva; and South Pacific Regional Environment Programme, Noumea.

4. Crocombe, R. G., 1987. Overview: The pattern of change in Pacific Land tenures. Land Tenure in the Pacific. 3rd edition. University of the South Pacific, Suva.

5. Crocombe, R. G., 1968. Improving Land Tenure. Technical Paper No. 159. South Pacific Commission, New Caledonia, Noumea.

6. Crocombe, R. G., 1989. The South Pacific: An Introduction. 5th edition. Institute of Pacific Studies, University of the South Pacific, Suva.

7. de Soto, X., 1993.

8. Dutt, B. \& Volavola, M., 1977. History of Land Surveying in Fiji. Ministry of Lands and Mineral Resources, Suva. 


\section{TRADITIONAL LAND TENURE ISSUES FOR LIS IN FIJI}

9. Eaton, C., 1988. Vakavanua land tenure and tobacco farming. Rural Fiji. Institute of Pacific Studies, University of the South Pacific, Suva.

10. Ezigbalike, I. C. \& Benwell, G. L., 1992. "Cadastral 'Reform' - What They Never Tell You About The Cultural Costs”. Proceedings of the International Conference on Cadastral Reform ' 92. Department of Surveying and Land Information, The University of Melbourne, Melbourne.

11. France, P., 1969. The Charter of the Land: Custom and Colonisation in Fiji. Oxford University Press, Melbourne.

12. Lloyd, D. T., 1982. Land Policy in Fiji. Occasional Paper No. 14. Department of Land Economy, University of Cambridge.

13. Moynagh, M., 1978. Land Tenure in Fiji's sugarcane districts since the 1920's. Journal of Pacific History, 13: 1-2.

14. Native Land Trust Board 1989 Annual Report.

15. Nayacakalou, R. N., 1971. Fiji: Manipulating the System. Land Tenure in the Pacific. Oxford University Press, Melbourne.

16. Overton, J. (ed.), 1988. Rural Fiji. University of the South Pacific, Suva.

17. Prasad, P. C., 1984. Fiji: Sugar Cane Production and Land Tenure. Land Tenure and Rural Productivity in the Pacific Islands. FAO, Rome; Institute of Pacific Studies, University of the South Pacific, Suva; and South Pacific Regional Environment Programme, Noumea.

18. Ravuvu, A., 1988. Development or Dependence: The Pattern of Change in a Fijian Village. Institute of Pacific Studies, University of the South Pacific, Suva.

19. Ravuva, A., 1987. The Fijian Ethos. Institute of Pacific Studies, University of the South Pacific, Suva.

20. Scarr, D., 1984. Fiji: A short history. George Allen \& Unwin, Sydney.

21. Spate, O. H. K., 1959. The Fijian People: Economic Problems \& Prospects. A report for the Legislative Council of Fiji, Council Paper No. 13 of 1959. Government Press, Suva.

22. Sutherland, W., 1992. Beyond the Politics of Race: An alternative history of Fiji to 1992. Political and Social Change Monograph 15. Department of Political and Social Change, Australian National University, Canberra.

23. Tuisawau, Rt. M., 1992. The Fiji Times. 21 July 1992: 3.

24. Williamson, I. P., 1982. The Cadastral Survey Requirements of Developing Countries in the Pacific Region - with particular reference to Fiji. Survey Review, 26 (206): 355-366. 


\section{University Library}

\section{- M M I N E R VA A gateway to Melbourne's research publications}

Minerva Access is the Institutional Repository of The University of Melbourne

Author/s:

Rakai, Mele E. T.;Ezigbalike, I. C.;Williamson, I. P.

Title:

Traditional land tenure issues for LIS in Fiji

Date:

1995

Citation:

Rakai, M. E. T., Ezigbalike, I. C., \& Williamson, I. P. (1995). Traditional Land Tenure Issues for LIS in Fiji. Survey Review, 33(258), 247-262.

Publication Status:

Published

Persistent Link:

http://hdl.handle.net/11343/34010 